\title{
Molecular identification of the swede midge (Diptera: Cecidomyiidae)
}

\author{
Juerg E Frey, ${ }^{1}$ Beatrice Frey \\ Molecular Diagnostics Laboratory, Department of Crop Protection, Agroscope FAW \\ Wädenswil, Swiss Federal Research Station for Horticulture, CH-8820 Wädenswil, \\ Switzerland \\ Robert Baur
}

Extension Service for Vegetable Production, Agroscope FAW Wädenswil, Swiss Federal Research Station for Horticulture, CH-8820 Wädenswil, Switzerland

The Canadian Entomologist 136: 771 - 780 (2004)

\begin{abstract}
Early detection of pest infestation is a prerequisite for sustainable crop protection. However, many pest species are difficult to detect and thus infestation is diagnosed from damage observed on the respective crop. This diagnosis is often made too late for implementation of crop protection measures, and serious crop losses may result. The swede midge, Contarinia nasturtii Kieffer, is a major pest of Brassica L. (Brassicaceae) vegetables in Europe that has recently invaded North America. With its small size and short adult life-span, and the cryptic lifestyle of the larvae feeding at the growing points of its host plants, it is usually detected only after damage has already occurred. Furthermore, because field-trapped specimens are rarely fully intact, it is extremely difficult to identify. Therefore, we developed a species-specific molecular diagnostic method that enables reliable identification of swede midge from various sources such as alcohol or sticky glue traps. The method enables large-scale screening of field-trapped specimens and is used to evaluate the attractiveness and specificity of pheromone traps that are currently under development.
\end{abstract}

Frey JE, Frey B, Baur R. 2004. Identification moléculaire de la cécidomyie du chou-fleur (Diptera : Cecidomyiidae). The Canadian Entomologist 136 : 771-780.

Résumé-La protection durable des cultures exige une détection précoce des infestations de ravageurs. Cependant, plusieurs espèces de ravageurs sont difficiles à déceler et, conséquemment, l'infestation n'est reconnue qu'au moment où des dommages apparaissent dans les cultures en question. Il est alors souvent trop tard pour mettre en oeuvre des mesures de protection des cultures, ce qui peut mener à des pertes agricoles importantes. La cécidomyie du chou-fleur, Contarinia nasturtii Kieffer, qui est un important ravageur des légumes du genre Brassica L. (Brassicaceae) en Europe, a récemment envahi l'Amérique du Nord. À cause de sa petite taille, de la courte durée de vie des adultes et du mode de vie caché des larves qui se nourrissent aux points de croissance des plantes hôtes, l'insecte n'est ordinairement remarqué qu'une fois que des dommages ont été faits. De plus, il est extrêmement difficile à identifier parce que les spécimens piégés en nature sont rarement tout à fait intacts. Nous avons donc mis au point une méthode moléculaire d'identification spécifique à cette espèce qui permet de déterminer de façon fiable les cécidomyies provenant de diverses sources, comme les pièges à alcool et à glu. La méthode permet le triage à grande échelle des spécimens récoltés en nature dans des pièges et sert à évaluer l'attraction et la spécificité des pièges à phéromones qui sont actuellement en train d'être mis au point.

[Traduit par la Rédaction]

${ }^{1}$ Corresponding author (e-mail: juerg.frey@faw.admin.ch). 


\section{Introduction}

The swede midge (SM), Contarinia nasturtii Kieffer, 1888 (Diptera: Cecidomyiidae), also known as the cabbage crowngall fly and cabbage gall midge, is a common pest of cole crops (Brassica L. spp. (Brassicaceae); e.g., cabbage, broccoli, cauliflower, and Brussels sprouts) in Europe and southwestern Asia. Recently, it has been detected in Canada (Hallett and Heal 2001), and there is much concern that it may invade the United States of America (Kikkert et al. 2002). Adult midges are small (approximately $1.7 \mathrm{~mm}$ ), yellowish brown, and have a short life-span of only up to 4 days (Skuhravá 1997; Kikkert et al. 2002). They are very difficult to distinguish morphologically from many other small midges. In spring, adult females lay their eggs in clusters on the growing point of the plant where, after only 3 days, the larvae hatch and start to feed on plant tissue near the growing point (Kikkert et al. 2002). Feeding causes damage symptoms that are difficult to diagnose because similar symptoms can be caused by several other factors, such as mechanical injury, hormonal herbicide injury, or heat or cold stress (Kikkert et al. 2002). The larvae are hidden, and the damage symptoms on crop plants are most often recognised only after the larvae have already completed their development and left the plant. Thus, growers and crop protection advisors have been unable to detect this pest early enough to prevent unacceptable crop loss. The damage causes changes in the physiology of the plant, resulting in blind plants (i.e., the head does not form), swollen petioles and flower buds, and brown corky scarring at the growing point (Kikkert et al. 2002). Infestations with SM can result in severe crop losses and therefore early identification of the pest is a prerequisite for sustainable vegetable production in areas where SM occurs.

SM identification is difficult even with well-preserved specimens, but it is almost impossible with field-collected specimens (e.g., from yellow pan traps or sticky traps). Therefore, to enable precise species identification of field-trapped specimens, we developed a PCR-based, species-specific diagnostic test for SM that enables screening of large numbers of midges economically and with modest effort. The mitochondrial cytochrome oxidase subunit I gene $(C O I)$ was recently shown to be ideally suited as a marker for species identification of many insects (Brunner et al. 2002; Hebert et al. $2003 a, 2003 b$ ). This is because the gene shows very limited variation within species yet clear differentiation between species. Cluster analyses of such genetic species markers thus show generally high bootstrap support for each species in dendrograms (Cipriano and Palumbi 1999; Brunner et al. 2002). We may therefore assume that insects that appear in the same cluster with a high bootstrap value represent a species or a species group with very low genetic differentiation. The test developed here is an important component of the efforts of three research groups that have joined to develop a speciesspecific pheromone trap (Y Hillbur et al., Department of Crop Science, Swedish University of Agricultural Sciences, Alnarp, Sweden; W Francke et al., Institute of Organic Chemistry, University of Hamburg, Germany; R Baur et al., Extension Service for Vegetable Production, Agroscope FAW Wädenswil; Hillbur et al. 2004). One major problem in developing pheromone traps for pest species that are difficult to identify morphologically is testing the field specificity of the synthetic pheromone mix. Synthetic pheromones may be attractive in wind-tunnel tests but may vary in their degree of species specificity, depending on the components and their ratio in the synthetic pheromone blend. For example, we previously showed that a synthetic pheromone designed in wind-tunnel experiments for high attractiveness to the scale species Quadraspidiotus perniciosus (Comstock, 1881) (Coccoidea: Diaspididae) attracted large numbers of another scale species, Quadraspidiotus zonatus (Frauenfeld, 1868), in field trials (Frey and Frey 1995). The present study thus combines two benefits, allowing 
molecular identification of field-trapped specimens and enabling optimization of the composition of synthetic pheromone blends.

\section{Materials and methods}

\section{Insect material}

The SM and other Diptera species used in this study originated from two main sources. Individuals were collected as adults from laboratory cultures or as larvae and (or) pupae from infested fields (source 1), or from pheromone-baited paper traps (source 2).

\section{Insect material from source 1}

The SM from our laboratory culture were reared on broccoli plants (population code = Zucht; see Fig. 1). Identification of this culture was based on Skuhravá (1997), and the following characters were used: antennae with 2 basal segments and 12 flagellomeres, flagellomeres of males binodose with nodes almost equal in size and shape, each bearing a single whorl of circumfilar loops; vein R5 straight (not curved backwards), joining costa at wing apex; wing surface covered with microtrichia; body greyish yellow; ovipositor long, needle-shaped, and retractile. Voucher specimens were identified by M Skuhravá (Prague, Czech Republic) in 1998 and deposited in the collection of our research station, Agroscope FAW Wädenswil. The first SM analyzed were reared from larvae collected in a heavily infested broccoli field. All evidence suggested that these specimens were $C$. nasturtii: Cecidomyiidae species are, in general, highly host-specific (Hill 1987; Skuhravá 1997); no other morphologically similar pests belonging to the supertribe Cecidomyiidi are known to have, as larvae, similar feeding habits on Brassica crops (Barnes 1946; Skuhravá 1997); and all morphological characters of the reared specimens were typical of $C$. nasturtii. DNA sequences from individuals of this culture were used as $C$. nasturtii reference sequences. In addition, we obtained larvae collected from infested Brassica crops from Schifferstadt, Germany (Schiff), Braunschweig, Germany (Braun), Stouffville, Ontario, Canada (Stouff03), and Hillsburg, Ontario, Canada (Hills02). The other species analyzed here were obtained from various sources: Contarinia tritici (Kirby, 1798) from Västeras (Vaest), Sweden; Contarinia pisi (Winnertz, 1854) from Troyes, France; and Mayetiola destructor (Say, 1817) from a laboratory culture at Purdue University, West Lafayette, Indiana, United States of America. Contarinia tritici and $C$. pisi were included in our study because, owing to crop rotation schemes commonly used in Europe (Koblet 1965), these species are the most likely among the agronomically relevant Contarinia species to occur in large numbers close to Brassica fields and may thus appear in significant numbers on the pheromone traps. Three species of Delia (Diptera: Anthomyiidae) (D. antiqua (Meigen, 1826), D. radicum (L., 1758), and D. platura (Meigen, 1826)) originated from our laboratory cultures, and two unidentified species of Sciaridae (Diptera; Scia1 and Scia2) were trapped in greenhouses (FAW). Most material was stored in $70 \%$ ethanol in the refrigerator until used; however, some individuals were placed individually in Eppendorf tubes and kept frozen until used. Voucher specimen of all species were deposited in the collection of Agroscope FAW Wädenswil.

\section{Insect material from source 2}

SM were also obtained from pheromone-baited white paper traps (Pheronet, Alnarp, Sweden) in the form of an open triangle lined with cardboard covered with a thin layer of Tangle-Trap ${ }^{\circledR}$ insect trap coating (The Tanglefoot Co, Grand Rapids, 
Michigan, United States of America). The traps were exposed to free-living SM in broccoli and Brussels sprouts fields in the region around Kerzers, Cantone Berne (Muentschemier $=$ Muent; Ins, collected in 2001 and $2002=$ Ins01 and Ins02, respectively), from the Cantone Thurgau (Tägermos = Taeger), and from the Cantone Aargau (Rütihof = Rueti), Switzerland. Unidentified species (U) were small Nematocera with body size and shape similar to that of typical Contarinia species (i.e., $1.5-2.0 \mathrm{~mm}$ in length, long legs, slim body); these species were collected from delta traps baited with an experimental mixture of candidate pheromone components that was later shown to be not attractive for SM (U_Ins01, U_Ins02, and U_Muent). The traps were exposed in the cabbage fields from July to September, thus covering a large part of the 3-5 generations of SM occurring in one year in Switzerland. The pheromone traps containing the caught insects were stored at $4{ }^{\circ} \mathrm{C}$ until used.

\section{DNA extraction and PCR amplification}

Individuals stored in ethanol (adults and larvae were equally suitable) were first dried on a filter paper (No. 595, Schleicher and Schuell, Dassel, Germany) before processing, while those caught on the pheromone traps and those kept frozen in the Eppendorf tubes were directly transferred to extraction buffer (Dilworth and Frey $2000 a, 2000 b)$ using a sterile wooden toothpick. The samples were homogenized in $100 \mu \mathrm{L}$ of extraction buffer using a mixer mill (Retsch MM300, QIAGEN AG, Basel, Switzerland). A 440-bp fragment of the mitochondrial COI gene was amplified from $1 \mu \mathrm{L}$ of the homogenate in a first-round PCR reaction containing $10 \mu \mathrm{L}$ of HotStarTaq Master Mix (QIAGEN) and $0.3 \mu \mathrm{mol} / \mathrm{L}$ of each primer (C1-J-1751, GGATCACCTGATATAGCATTCCC; C1-N-2191, CCCGGTAAAATTAAAATATAAACTTC; Simon $e t$ al. 1994) in a $20-\mu \mathrm{L}$ reaction. The reaction was performed in a PerkinElmer ${ }^{\circledR} 9600$ thermocycler using $15 \mathrm{~min}$ initial denaturation, followed by 40 cycles of $40 \mathrm{~s}$ denaturation at $95{ }^{\circ} \mathrm{C}, 40 \mathrm{~s}$ annealing at $52{ }^{\circ} \mathrm{C}$, and $40 \mathrm{~s}$ extension at $72{ }^{\circ} \mathrm{C}$, and finally $7 \mathrm{~min}$ at $72{ }^{\circ} \mathrm{C}$.

\section{DNA sequencing}

The PCR products were cleaned over silica columns (QIAGEN), and a sequencing reaction with $20 \mathrm{ng}$ of DNA was performed with BigDye ${ }^{\circledR}$ Terminator Ready Reaction mix (Applied Biosystems, Rotkreuz, Switzerland) on an ABI PRISM ${ }^{\circledR} 3100$ Sequence Detection System (Applied Biosystems) according to the manufacturer's recommendations. Sequences that differed from any of the confirmed haplotypes by only $1 \mathrm{bp}$ were discarded. Cluster analysis was performed solely to differentiate between species and not to evaluate phylogenetic relationships. We used the software PAUP $4.0 \mathrm{~b} 10$ for a maximum likelihood analysis based on the GTR+G+I model (general time reversible model with gamma distribution and invariable sites; Rodriguez et al. 1990), as evaluated using Modeltest version 3.06 (Posada and Crandall 1998) and 500-replicate bootstrapping. Neighbor-joining cluster analysis based on the Kimura 2-parameter model was performed with the software MEGA version 2.1 (Nei and Kumar 2000).

\section{Marker testing}

In our laboratory we have obtained sequence information for many individuals of 67 arthropod species and, so far, the COI marker has always shown clear species differentiation (unpublished data). In Contarinia, this marker has already been used to verify that Contarinia maculipennis Felt, 1933 is a single polyphagous species rather than a complex of host-associated cryptic species (Uechi et al. 2003). However, as it is generally not feasible to obtain DNA sequence information for all species within a genus, we 
cannot rule out the possibility that this marker is not suitable as a species identification marker for certain taxa, such as Diptera, that have not yet been properly evaluated. To further test the suitability of the amplified $C O I$ fragment as a species-specific marker in Diptera, we used the 500 best-match Diptera DNA sequences to SM haplotype 35 from GenBank (http://www.ncbi.nlm.nih.gov/). Of these sequences, 496 could be aligned and were clustered by a neighbor-joining cluster analysis based on the Kimura 2-parameter model with 100-replicate bootstrapping. In addition to the species that we sequenced, the analysis included 123 Diptera species from 16 families or superfamilies: 6 Agromyzidae spp.; 3 Anthomyiidae spp.; 19 Calliphoridae spp.; 14 Cecidomyiidae spp.; 1 species from each of Ceratopogonidae, Cordyluridae, and Pipunculidae; 19 Culicidae spp.; 4 Culicoidea spp.; 5 Drosophilidae spp.; 2 species from each of Muscidae, Sciaridae, Sarcophagidae, Simuliidae, and Tephritidae; 33 Syrphidae spp.; and 7 unknown species. Sequences for the following Cecidomyiidae species were among the GenBank sequences (number of individuals in parenthesis): Asphondylia conglomerata Stefani, 1900 (5), Asphondylia gennadii (Marchal, 1904) (12), Asphondylia sarothamni (Loew, 1850) (1), Asphondylia yushimai Yukawa et Uechi, 2003 (30), two unidentified Asphondylia species (10), C. maculipennis (50), and Contarinia okadai Miyoshi, 1980 (1). All species were clearly separated with strong bootstrap support. Species that were represented by only one individual never appeared within a cluster of another species (unpublished data). This provides strong support for the assertion that the amplified COI fragment is suitable as a species identification marker in Diptera.

\section{Species-specific primer design and PCR}

To avoid the need for DNA sequencing for SM identification, we followed a strategy similar to that established by DeSalle and Birstein (1996) for PCR identification of black caviar. For species-specific identification of SM, a second-round, nested PCR reaction was performed with the species-specific primers SM_NF1 and SM_NR1 (Table 1). The primers were designed based on a ClustalX alignment of all COI sequences, choosing sites with maximal variation among taxa. We used $1 \mathrm{ng}$ of first-round PCR product cleaned with the QIAquick PCR purification kit, following the protocol of the manufacturer (QIAGEN). We used the following cycling conditions: 15 min initial denaturation; 40 cycles of $40 \mathrm{~s}$ denaturation at $95{ }^{\circ} \mathrm{C}, 40 \mathrm{~s}$ annealing at $46{ }^{\circ} \mathrm{C}$, and $40 \mathrm{~s}$ extension at $72{ }^{\circ} \mathrm{C}$; and $7 \mathrm{~min}$ at $72{ }^{\circ} \mathrm{C}$. Optimal annealing temperature for the nested PCR was determined by testing temperatures between 40 and $56{ }^{\circ} \mathrm{C}$ on a gradient thermocycler (Eppendorf Mastercycler ${ }^{\circledR}$ gradient, Vaudaux-Eppendorf AG, Schönenbuch, Switzerland). An $8-\mu \mathrm{L}$ sample of the nested PCR product and $3 \mu \mathrm{L}$ of loading buffer $\left(15 \%\right.$ Ficoll $^{\circledR} 100$ with bromophenol blue) were mixed and electrophoresed on a $1.2 \%$ agarose gel at $70 \mathrm{~V} \cdot \mathrm{cm}^{-1}$ for $40 \mathrm{~min}$. Results were documented on an AlphaImager ${ }^{\circledR}$ Imaging System (IS-2000C-225, Alpha Innotech, Witec AG, Littau, Switzerland).

\section{Results and discussion}

Reliable, successful amplification of a COI fragment using the primers of Simon et al. (1994) was possible using both fresh samples and samples caught on pheromone traps and stored in ethanol for at least 2 years. Amplification products of the expected size were obtained from all samples. We found only four different haplotypes $(29,35$, 42, 43) among 163 sequenced SM individuals collected from several Swiss populations, from Germany, and from Canada (Fig. 1). This indicates low within-species variation in this genetic marker and supports our assertion and that of others that the COI gene is an ideal species identification marker in insects (Brunner et al. 2002; Hebert et al. 2003a, 


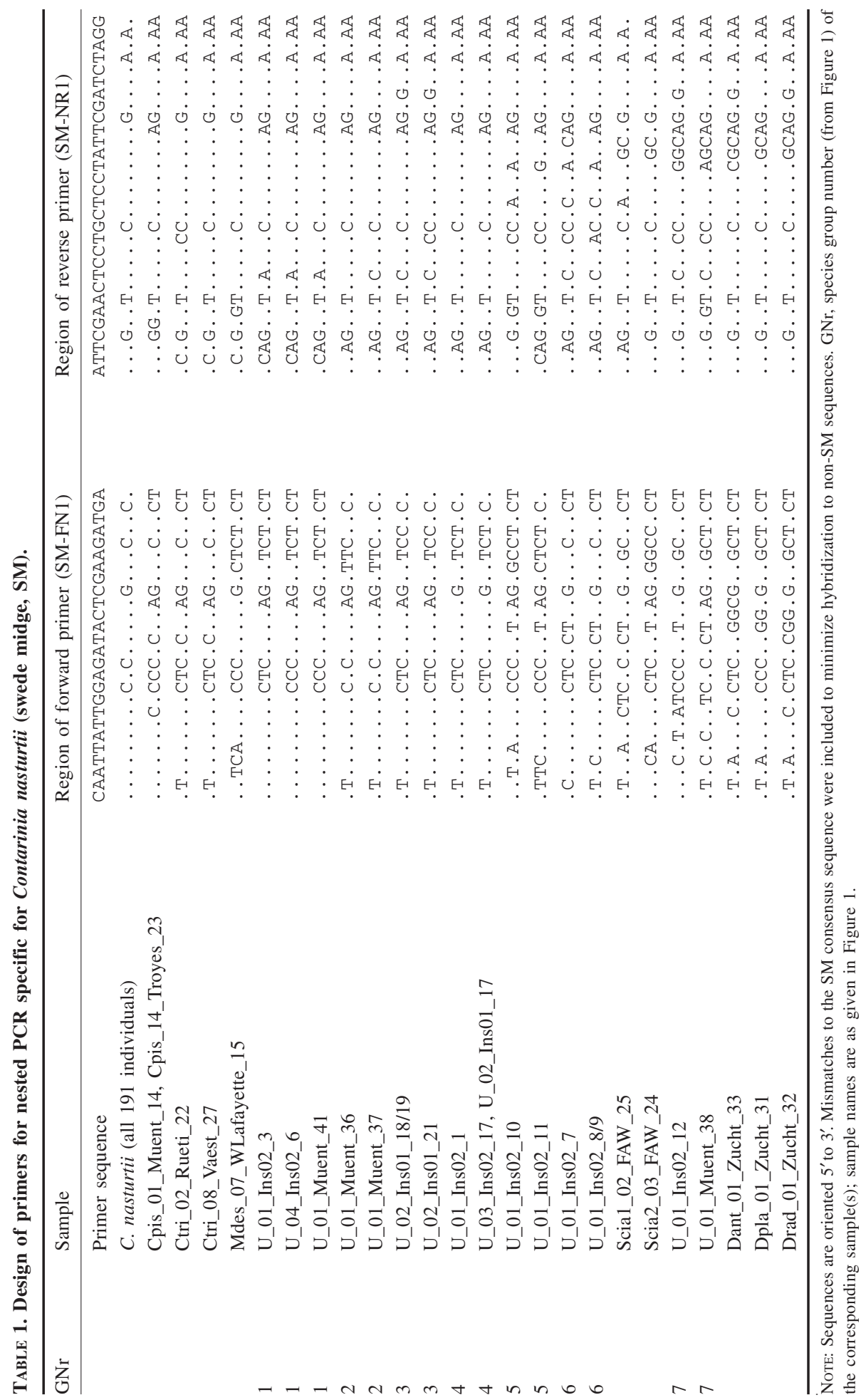




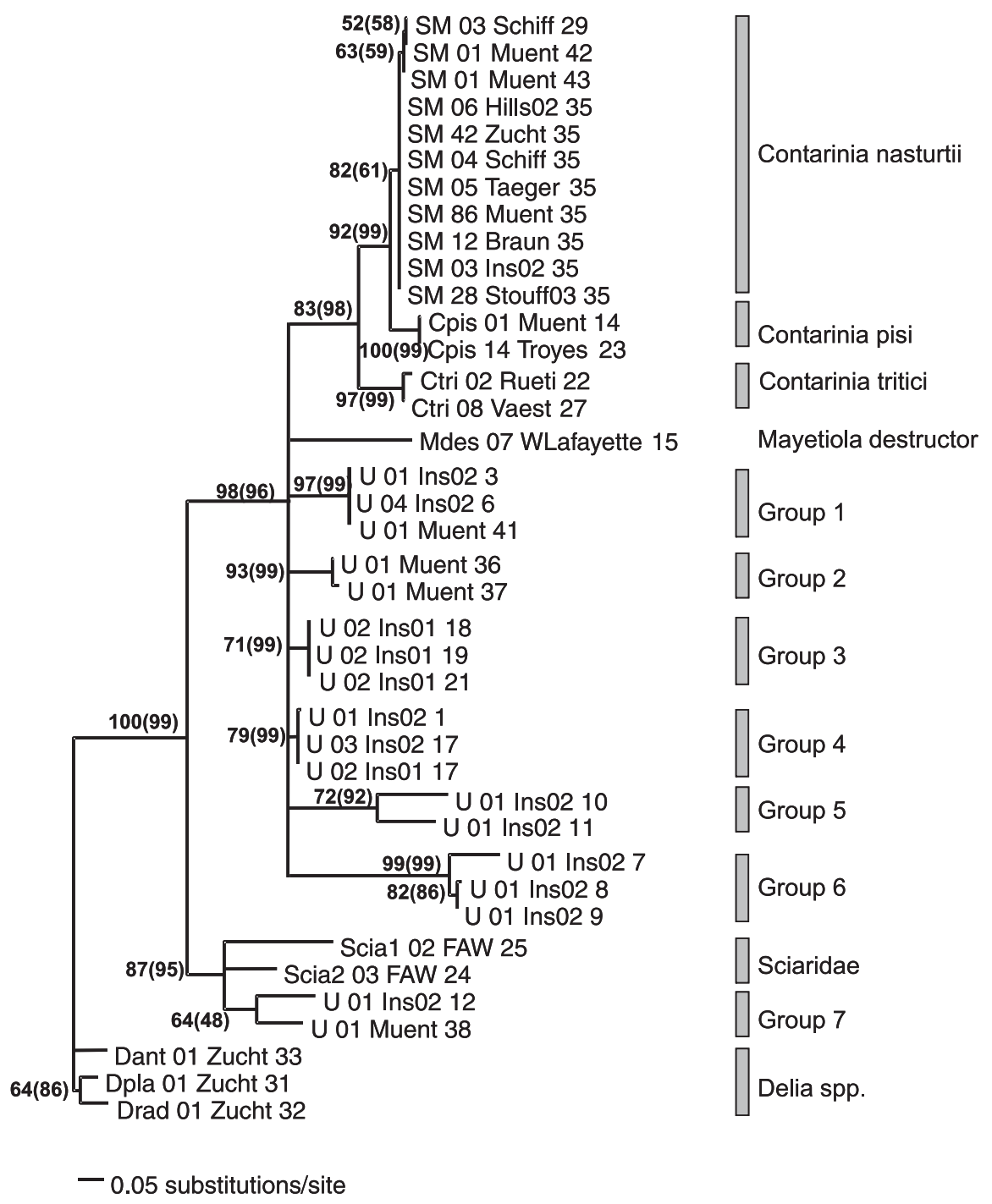

Figure 1. Maximum likelihood dendrogram showing genetic relatedness among identified and unidentified Diptera species. Individuals with identical haplotypes are collapsed unless they originated from different populations. Numbers on branches indicate bootstrap values for 500 replicates (in parentheses, 2000-replicate values for the corresponding neighbor-joining cluster analysis that resulted in the same species groups). Labels are as follows: species code (SM, Contarinia nasturtii (swede midge); Ctri, C. tritici; Cpis, C. pisi; Dant, Delia antiqua; Dpla, D. platura; Drad, D. radicum; Mdes, Mayetiola destructor; Scia1 and Scia2, unidentified Sciaridae species 1 and 2, respectively; U, unknown species), followed by the number of collapsed individuals, population code (as in Materials and methods), and a haplotype identification number. The cluster of SM includes identical haplotypes that were found in different populations (i.e., haplotype 35).

$2003 b$ ). With a frequency of $97 \%$, haplotype 35 was by far the most frequent haplotype and was found in all studied populations from all countries (GenBank accession Nos. AY485371-AY485378). The frequency of the second haplotype (29) was below 2\% and was found in the German population Schifferstadt (GenBank accession No. AY485370). The other two were each found in only a single individual in the largest of 
the screened populations (Muentschemier, Switzerland; GenBank accession Nos. AY485379 and AY485380). Two haplotypes were found in C. pisi (GenBank accession Nos. AY485381 and AY485382) and two in C. tritici (GenBank accession Nos. AY485369 and AY485383), while all seven specimens of $M$. destructor were identical (GenBank accession No. AY485387). Only one individual of each of the three Delia species used as outgroups was sequenced (GenBank accession Nos.: D. platura, AY485385; D. radicum, AY485386; D. antiqua, AY485384). The sequences of the unidentified species were also deposited in GenBank (accession Nos. AY485366AY485368 and AY485388-AY485404).

All identified species formed well-separated clusters with strong bootstrap support (Fig. 1). Furthermore, the three Contarinia species included in this study (i.e., SM, C. pisi, and C. tritici) form a single, well-supported cluster. The cluster analysis (used here solely for the purpose of species identification rather than the study of phylogenetic relationships among species) thus indicates that most flies trapped in the preliminary field trials with the experimental mixture of candidate pheromone components (later shown to be not attractive for SM) that showed some phenotypic similarity to the SM (i.e., populations U_Ins01, U_Ins02, and U_Muent) did not belong to the genus Contarinia. Only three of these field-trapped specimens (from Ins02) were identified as SM, and none belonged to either of the other two Contarinia species. This suggests that field-grown Brassica vegetables may be almost exclusively visited by only one Contarinia species, SM, resulting in ideal conditions for the use of a pheromone trap for early detection of SM infestation. However, the presence or absence of other Contarinia species or species from closely related genera in a broccoli field may depend upon the field's environment and the cultural practices of the farmer. For example, certain weeds are hosts of some Contarinia species (e.g., several alfalfa (Medicago L., Fabaceae) species are hosts of Contarinia medicaginis Kieffer, 1895; Barnes 1946). Furthermore, weeds and other crops that may have preceded the broccoli crop may have been infested with Contarinia species that are present in the current crop as pupae and will eventually emerge. Closely related species tend to use similar pheromone components to attract their respective mating partners (Witzgall et al. 2004), and Hillbur et al. (2000) suggested that this may be especially true for species of the family Cecidomyiidae. Although artificial pheromones may be attractive in wind-tunnel tests, they may vary in their degree of species specificity in the field, depending on the components and their ratio in the synthetic pheromone blend (Harris and Foster 1999). Therefore, these Contarinia species may serve as a reservoir for potential contamination of the pheromone traps. It is thus recommended that the species specificity of synthetic pheromone blends be carefully validated in the field prior to large-scale use.

To enable large-scale screening for the occurrence of SM, we developed a species-specific, PCR-based diagnostic method. The nested design of the assay allowed us to assess $(i)$ the success of DNA extraction and PCR amplification in a first-round PCR and (ii) species-specific SM typing in a second, nested amplification. The nested primers were designed to exclusively match SM sequences. However, mismatches to the SM consensus sequence were introduced to increase the power of the assay to discriminate non-SM sequences (Cha et al. 1992; Table 1). Using these primers with diluted firstround PCR product, amplification was successful only if the template DNA was SM DNA (Fig. 2). The PCR product had the expected size of $285 \mathrm{bp}$. We validated the assay by running members of all clusters of the unknown species as well as all identified species (Fig. 2). This established species specificity of the assay with respect to fieldtrapped flies showing some phenotypic resemblance to SM. Use of the assay in areas far from Central Europe would require reevaluation of this aspect.

In conclusion, we have established a robust, species-specific, PCR-based diagnostic method for SM identification that enables large-scale screening of field-trapped 

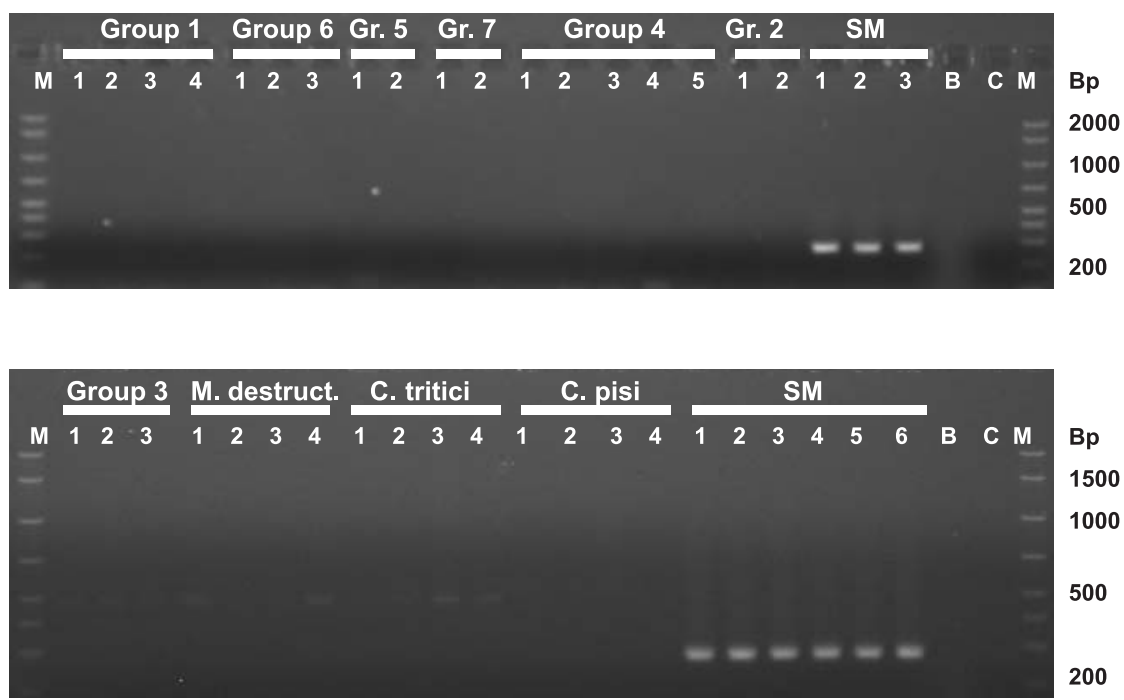

Figure 2. Result of nested PCR amplification specific for Contarinia nasturtii. Successful amplification occurs only with $C$. nasturtii DNA as template. Numbers indicate different individuals belonging to each of the species groups (as suggested by the phylogenetic analysis; see Figure 1). B, blank; C, negative control reaction; $M$, size marker; $B p$, base pairs.

specimens. The assay is currently being used to optimize the species-specificity of a synthetic SM pheromone that is under development in a European collaborative project.

\section{Acknowledgements}

We thank J Samietz, P Brunner, M Pfunder, and two anonymous reviewers for their valuable comments on an earlier version of this manuscript, and J Stuart, Purdue University, United States of America; K Callow, Ministry of Agriculture and Food, Guelph, Ontario, Canada; Y Hillbur, Swedish University of Agricultural Sciences, Alnarp, Sweden; G Siekmann, Biologische Bundesanstalt Braunschweig, Germany; and J Kreiselmaier, SLFA Neustadt/Weinstrasse, Germany, for supplying us with insect material.

\section{References}

Barnes HF. 1946. Gall midges of economic importance. Volume II. Gall midges of fodder crops. London: Crosby Lockwood and Sons

Brunner PC, Fleming C, Frey JE. 2002. A molecular identification key for economically important thrips species (Thysanoptera: Thripidae) using direct sequencing and a PCR-RFLP-based approach. Agricultural and Forest Entomology 4: 127-36

Cha RS, Zarbl H, Keohavong P, Thilly WG. 1992. Mismatch amplification mutation assay (MAMA): application to the c-H-ras gene. PCR Methods and Applications 2:14-20

Cipriano F, Palumbi SR. 1999. Genetic tracking of a protected whale. Nature (London) 397: 307-8

DeSalle R, Birstein VJ. 1996. PCR identification of black caviar. Nature (London) 381: 197-8

Dilworth E, Frey JE. 2000a. A rapid method for high throughput DNA extraction from plant material for PCR amplification. Plant Molecular Biology Reporter 18: 61-4

— 2000b. Erratum: a rapid method for high throughput DNA extraction from plant material for PCR amplification. Plant Molecular Biology Reporter 18: 157

Frey JE, Frey B. 1995. Molecular identification of six species of scales (Quadraspidiotus sp.) by RAPDPCR: assessing the field-specificity of pheromone traps. Molecular Ecology 4: 777-80 
Hallett RH, Heal JD. 2001. First Nearctic record of the swede midge (Diptera: Cecidomyiidae), a pest of cruciferous crops from Europe. The Canadian Entomologist 133: 713-5

Harris MO, Foster SP. 1999. Gall midges. pp 27-49 in J Hardie (Ed), Pheromones of non-lepidopteran insects associated with agricultural plants. Oxford: CAB International

Hebert PDN, Cywinska A, Ball SL, deWaard JR. 2003a. Biological identifications through DNA barcodes. Proceedings of the Royal Society of London, Series B: Biological Sciences 270: 313-22

Hebert PDN, Ratnasingham S, deWaard JR. 2003b. Barcoding animal life: cytochrome c oxidase subunit 1 divergences among closely related species. Proceedings of the Royal Society of London, Series B: Biological Sciences 270(Supplement 03BL0066): 1-4

Hill DS. 1987. Agricultural insect pests of temperate regions and their control. London: Cambridge University Press

Hillbur Y, El-Sayed A, Bengtsson M, Löfqvist J, Biddle A, Plass E, Francke W. 2000. Laboratory and field study of the attraction of male pea midges, Contarinia pisi, to synthetic sex pheromone components. Journal of Chemical Ecology 26: 1941-52

Hillbur Y, Celander M, Baur R, Rauscher S, Haftmann J, Franke S, Francke W. 2004. Identification of the sex pheromone of the swede midge, Contarinia nasturtii. Journal of Chemical Ecology. In press

Kikkert JR, Hoepting CA, Shelton AM. 2002. Swede midge. Fact Sheet Page 751.3 [online]. Cornell Cooperative Extension, Cornell University, Ithaca, New York. Available from http://www.nysipm.cornell. edu/factsheets/vegetables/cruc/sm.pdf [cited 29 September 2004]

Koblet R. 1965. Der landwirtschaftliche Pflanzenbau. Basel, Switzerland: Birkhäuser-Verlag

Nei M, Kumar S. 2000. Molecular evolution and phylogenetics. New York: Oxford University Press

Posada D, Crandall KA. 1998. MODELTEST: testing the model of DNA substitution. Bioinformatics 14: $817-8$

Rodriguez F, Oliver JF, Marin A, Medina JR. 1990. The general stochastic model of nucleotide substitution. Journal of Theoretical Biology 142: 485-501

Simon C, Frati F, Beckenbach A, Crespi B, Liu H, Flook P. 1994. Evolution, weighting, and phylogenetic utility of mitochondrial gene sequences and a compilation of conserved polymerase chain reaction primers. Annals of the Entomological Society of America 87: 651-701

Skuhravá M. 1997. 2.7 - Family Cecidomyiidae. pp 71-204 in L Papp, B Darvas (Eds), Contributions to a manual of Palearctic Diptera. Volume 2. Nematocera and lower Brachycera. Budapest, Hungary: Science Herald

Uechi N, Tokuda M, Yukawa J, Kawamura F, Teramoto KK, Harris KM. 2003. Confirmation by DNA analysis that Contarinia maculipennis (Diptera: Cecidomyiidae) is a polyphagous pest of orchids and other unrelated cultivated plants. Bulletin of Entomological Research 93: 545-51

Witzgall P, Lindblom T, Bengtsson M, Tóth M. 2004. The pherolist, Internet edition [online]. Available from http://www-pherolist.slu.se/pherolist.php [cited 29 September 2004]

(Received: 24 December 2003; accepted: 17 August 2004) 